\title{
Response of Cowpea Varieties to Basal Stem Rot (Sclerotium rolfsii) Disease in Southern Guinea Savanna, Nigeria
}

\author{
MU Tanimu*, IU Mohammed, A Muhammad and NM Kwaifa \\ Department of Crop Science, Kebbi State University of Science and Technology, Nigeria
}

Submission: Novmeber 29, 2017; Published: April 25, 2018

"Corresponding author: MU Tanimu, Department of Crop Science, Faculty of Agriculture, Kebbi State University of Science and Technology, Aliero, Nigeria, Email: musa.umartanimu@ksusta.edu.ng

\section{Abstract}

Background: Cowpea is an important crop for resource poor farmers across Africa. However, the crop is susceptible to a range of diseases which severely reduce yields, including Basal Stem Rot Disease (BSRD) caused by Sclerotium rolfsii.

Methods: The aim of this study was to evaluate five cowpea varieties (L-25, Ife brown, IT89 - KD - 374, IT89 - KD-434 and IT86 - D 715) for resistance to Basal Stem Rot Disease (BSRD). The research was conducted at the National Cereals Research Institute Badeggi in the Southern Guinea Savannah zone of Nigeria during 2010/2011 wet cropping season. The BSRD pathogen was artificially inoculated onto stem of the varieties with mycelia disc and sclerotia. The inoculation methods included wounding and non-wounding. Healthy plants inoculated with distilled water were used as a control.

Results: Result revealed that, L - 25, IT89 - KD-434 and IT86 - D - 715 were immune to infection by the pathogen, while IT89 - Kd - 434 and Ife brown were susceptible. The effect of the pathogen on plant characteristics like plantestablishment,plant height and seed weight were significant $(P=0.05)$ in those varieties affected.

Conclusions: In areas where BSRD is not found, farmers should adopt Ife - brown and IT86-D-715 because they have the highest establishment percentage. IT89-KD-434 is also recommended in such areas because it gave the best average seed weight. In areas affected by BSRD varieties L-25, IT89-KD-374 and IT86-D-715 are recommended as they are resistant to the pathogen and should be made available at subsidized rates. Research is also needed to develop more cowpea varieties resistant to the pathogen.

Keywords: Cowpea; Sclerotia; Inoculation; Mycelia; Pathogen; Basal stem rot (BSRD); Immune; Southern guinea savannah

\section{Introduction}

Cowpea was known in India for a long time [1]. It was introduced to U.S.A in the late 17th Century by the Spanish and more cultivars were transported there from West Africa during the slave trade [2]. They further, suggested that cowpea was domesticated in the sub humid and semi-arid regions of West Africa from a natural colonizer that evolved from the wild perennial progenitor. Recent studies [1] showed that more than 10,000 accessions were from Nigeria, Niger Republic, Burkina Faso and China. Cowpea is grown extensively in 16 African countries with Africa producing two - thirds of the total world production [1]. Nigeria and Niger Republics produced $2.92 \mathrm{~m}$ and $1.10 \mathrm{~m}$ tonnes respectively, and Myanmar with $0.15 \mathrm{~m}$ tons between 2006 and 2008 [3]. Cowpea is an important source of protein as the seeds contain $24 \%$ of protein, $63.6 / \%$ carbohydrate $1.9 \%$ fat $6.3 \%$ fibre [1]. More than $50 \%$ of the starch is in the form of amylase [4]. The amount of amylose in the starch influences starch solubility, lipid binding and many functional properties such as swelling and water absorption that affect the cooking properties and acceptance. Cowpea as food legume has important nutritional characteristics of complementing cereals grains [4]. For example cowpea maize mixtures, provide the highest quality protein at weight ratio of 45 parts maize to 15 parts cowpea [1]. Cowpea plays a critical role in the lives of millions of people in Africa and other parts of the developing world, it is a major source of dietary protein and is a valuable and dependable commodity that produces income for farmers and traders $[5,6]$. Low yields of cowpea are a significant attribute of production particularly in Africa and Asia where $240-300$ $\mathrm{kg} / \mathrm{ha}$ are typical. Increase in seed production is hindered by biotic pressures particularly insect pests, bacteria, fungal or viral diseases which often affect the cowpea plant throughout its life 
cycle and when grains are in storage. One of the major diseases/ of cowpea is basal stem rot caused by the fungal pathogen Sclerotium rolfsii. This pathogen is known to be an unspecialized parasite inhabiting the soil and very wide spread particularly in warm wet climate areas [7]. It also survives in organic matter [8] as sclerotia. The survival time is apparently very variable (a few weeks to greater than one year) [8]. According to [9] Sclerotium rolfsii grows, survives and attacks plant at or near the soil surface. Before the pathogen penetrates through host tissue, it produces considerable mass of mycelium on the plant surface; this process takes about 2-10 days. Penetration into host tissue occurs when the pathogen produces an enzyme which deteriorates the host outer cell layer; this results in decay, further production of mycelium and sclerotia [9]. High amounts of organic matter in the soil increase inoculums potential [8]. The pathogenicity of the pathogen has been attributed to the exogenous production of oxalic acid a non-specific metabolite [10] and to the production of a wide range of enzymes for carbohydrate metabolism [8]. Sclerotium rolfsii has an extensive host range over 189 plant species [8]. This ranges from mosses to composites. The first symptoms are usually seen as a leaf yellowing and wilt [11]. The cortical decay occurs on the stem at about ground level with conspicuous mycelium appearing and spreading or extending into the soil and on organic debris [10], stem infection may be followed by infection of the upper root and stem tubers. Mycelia growth and formation of sclerotia is high at 25-35\% (optimum $30{ }^{\circ} \mathrm{C}$ ) [12]. Direct penetration of the host occurs, although entry is through wound [9]. Out breaks of basal stem rot has an erratic distribution [7] they also have been associated with warm moist conditions [8]. According to [1] who investigated the reaction of cowpea varieties to infection by Sclerotium rolfsii, twenty cowpea varieties were screened for infection by the pathogen; no variety was immune but plant reactions ranged from resistant to highly susceptible varieties IAR - 339 - 1, IT84 - E - I - 108 and IT81 - D - 975 were moderately resistant and IT - 8RE - 9 and $\mathrm{K}-59$ were susceptible. Apart from causing basal stem rot, the pathogen is known to cause pod and branch rot in cowpea [11]. According to [9], the disease had symptoms of concentric brown rings of necrotic tissues with diameter ranging from 0.3$3.6 \mathrm{~cm}$ formed on leaves. Pods and branches on the other hand were covered with brown lesions of mycelium and sclerotia. In Nigeria, Okereke V C [13] described it as basal rot because it affects mainly the stem at the soil level. In India, the same organism causes leaf blight and a mortality of up to $20 \%$ in $5-10$ day old seedlings in cowpea [5]. The pathogenicity of Sclerotium rolfsii is affected by temperature [10]. According to [14]; the effect of melanisation and myceliogenic germination of sclerotia (by temperature) of a normal strain of the fungus produced on potato dextrose agar at different temperatures of 7,16 and 300C were black, while the colour of the aberrant strain was light brown, brown, or tan and dark brown under above listed temperatures respectively, they further explained that deposition of melanin substance was heavy both on the surface and inside the cell wall of black sclerotia formed at 70C. Nutritional factors,
$\mathrm{pH}$ and temperature influence growth of the pathogen [15]. The report showed that mycelia growth was least at 300C and $\mathrm{pH}$ 5.0 while most sclerotia were formed at $25{ }^{\circ} \mathrm{C}$ and pH1.0. Dry sclerotia of this fungus were in-activated completely by heating in water at $50{ }^{\circ} \mathrm{C}$ for 80 minutes and hosts included cultivated crops such as cowpea sweet potato, yams, cassava, onion, Cotton, kenaf Okra etc. [12]. The nature of resistance is not clearly defined; Langyintuo AS [5] attributed it to single dominant gene. They explained that examination of the comparative frequency distributions of the parental and progeny populations of the "Carolina Cream" x "Magnolia Blackage" and the corresponding segregation data indicates that the southern blight resistances exhibited by Carolina Cream" and Brown Crowder" are conditioned by single dominant genes; and again examination of the segregation data from the parental and progeny populations of the "Carolina cream " $x$ brown Crowder" cross suggest that the two resistance genes are not allelic. The availability of each of the resistance genes into cultivar-type genetic backgrounds should allow for rapid incorporation of southern blight resistance genes into other cowpeas cultivars by the application of conventional plant breeding methodologies [17]. Varietal resistance to this pathogenic organism has been demonstrated in number of hosts. They attributed this resistance to an impervious cuticle, thick walled or cortical cells and cork cambium activity. It is as a result of the susceptibility of cowpea to the pathogen that these cowpea varieties were selected and screened for resistance with the following objectives. The broad objective of this research is to screen the selected cowpea varieties for resistance to S. rolfsii or basal stem rot disease, while the specific objectives of the study are to:

i. Find out the effect of the pathogen on the respective cowpea varieties.

ii. Screen the five varieties of cowpea for resistance against the attack of the pathogen

iii. Make a possible recommendation about the best variety/varieties that is resistant to the pathogen.

\section{Materials and Methods}

Field experiment was carried during 2010 wet cropping season at the National Cereals Research Institute Headquarters Badeggi Headquarters in Southern Guinea Savannah Zone. It involved both Screen house and Laboratory studies.

\section{Inoculum Source}

The sclerotia of the Sclerotium rolfsii used as inoculum was obtained from a susceptible grass host Echinochloa spp on a cowpea farm during the 2010 wet cropping season, the sclerotia was dried and stored in Petri-dishes this was left inincubator at a temperature of $30^{\circ} \mathrm{C}$.

\section{Fungus Identification}

Fungal identification was based on the morphological characteristics. The fungus developed white radial growth 
mycelia, with hyaline, thin and septate hyphae, which represented scattered branching and characteristic fibulae. On these mycelia, the fungus also formed small, white globose sclerotia, which subsequently turned from light brown to dark brown and were $0.6-1.2 \mathrm{~mm}$ in diameter

\section{Preparation of Culture Medium}

Two hundred gram of peeled potato was cut into about $1 \mathrm{~cm}^{3}$ cubes boiled gently with about $600 \mathrm{~cm}^{3}$ of distilled water for 1hour it was allowed to cool after which the supernatant was decanted into 1 litre by addition of distilled water. Twenty grams of dextrose (glucose) and twenty grams of agar (solidifier) was weighed and added to supernatant in the measuring cylinder. This was autoclaved to homogenize for about twenty minutes. The homogenised solution was distributed into medical bottle and sterilized at $121{ }^{\circ} \mathrm{C}$ temperature $1.1 \mathrm{kgm}^{2}$ pressure for fifteen minutes. This was dispersed into sterile $9.0 \mathrm{~cm}$ diameter Petri dishes in $10-15 \mathrm{ml}$ portions and allowed to cool. Spirit lamp was used to flame the mouth of each bottle each time the medium was poured in the Petri-dish.

\section{Preparation of Inoculum}

Sclerotia was be picked from Petri-dishes by the use of a sterilized inoculating needle and then transferred into the centre of $9.00 \mathrm{~cm}$ diameter Petri-dish containing the potato dextrose agar (PDA) medium. This was done by dipping the forceps into methylated spirit and flaming, sclerotia was picked and transferred in the plate by carefully lifting the cover and placing it at the centre. The inoculated media was kept in the incubator at a temperature of $30{ }^{\circ} \mathrm{C}$ and the growth was observed until when they were used for inoculation of the cowpea plants in the screen house.

\section{Experimental Design}

Topsoil classified as sandy loam was collected from fallowed land within the Research institute farm. It was mixed for homogeneity and5-kg of the soil was measured into each pot. The five cowpea varieties; were sown into the pots and grown for two weeks before inoculation in a Randomized complete block design (RCBD). Light watering was followed after planting which was done in the morning. An alternate day watering was done when there was enough moisture in the soil. A total of 60 plants per variety were inoculated in three replicates $(60 \times 5$ x $3=900$ plants), ten healthy plants per variety were used as control. Plants were inoculated twenty days after planting (DAP) with 5-day old culture of Sclerotium rolfsii. A-5mm diameter cork borer was flame sterilized and was used to cut 5-mm diameter mycelia disc and placed on the stem near the soil level. Mycelia disc were placed on the created wounds. Plants were watered in the morning prior to the inoculation. Plant establishment at ten days after planting, lesions after inoculation were determined by visual observation of characteristic yellowish patches or spots on the leaves and reddish-brown patches on the stem, plant height and cowpea grain weight all these were recorded.

\section{Data Analysis}

The data generated was subjected to analysis of variance using general linear model (GLM) of the Statistical Analysis System package (SAS, 2003). The treatment means were separated using the least significant difference (LSD).

Results

The results obtained from screen house experiment (Table 1), shows that Ife brown established better than the remaining four varieties, followed by IT86 - D - 715. Varieties L - 25, IT89 KD - 374 and IT86 - D - 715 were not affected by necrotic lesion after inoculation, while IT89-KD-434 was most susceptible $(40 \%)$ than Ife brown $(25 \%)$

Table 1: Parameters recorded following mycelia inoculation.

\begin{tabular}{|c|c|c|c|}
\hline Varieties & $\begin{array}{c}\text { Percent } \\
\text { Establishment }\end{array}$ & $\begin{array}{c}\text { \% No. of Plants } \\
\text { with } \\
\text { Necrotic Lesion }\end{array}$ & $\begin{array}{c}\text { \% Size of } \\
\text { Lesion } \\
\text { After } \\
\text { Inoculation }\end{array}$ \\
\hline L-25 & 40 & 0 & 0 \\
\hline Ife- brown & 100 & 10 & 25 \\
\hline IT89-KD-374 & 40 & 0 & 0 \\
\hline IT89-KD-434 & 50 & 19.84 & 40 \\
\hline IT86-D-715 & 90 & 0 & 0 \\
\hline LSD & 2.16 & Ns & 3.48 \\
\hline
\end{tabular}

Effect of wounding on the lesion sizes of the varieties when inoculated $S$, rolfsii

The average size of lesions in the wounded and non-wounded inoculated plants was compared (Table 2). The lesions were more severe on the variety IT89-KD-434 $(6.50 \mathrm{~mm})$ as compared to Ife brown $(5.50 \mathrm{~mm})$. The difference between the sizes of the lesions from the wounded plants were significant at $\mathrm{P}=0.05$ ) between the varieties, with LSD 3.480 .

Table 2: Effect of wounding on the lesion sizes of the varieties.

\begin{tabular}{|c|c|c|c|c|}
\hline \multirow{2}{*}{ Varieties } & \multicolumn{2}{|c|}{ Non - Wounded } & \multicolumn{2}{c|}{ Wounded } \\
\cline { 2 - 5 } & $\begin{array}{c}\text { Length } \\
\text { (mm) }\end{array}$ & $\begin{array}{c}\text { Width } \\
\text { (mm) }\end{array}$ & $\begin{array}{c}\text { Length } \\
\text { (mm) }\end{array}$ & $\begin{array}{c}\text { Width } \\
\text { (mm) }\end{array}$ \\
\hline L-25 & 0.00 & 0.00 & 8.44 & 3.45 \\
\hline Ife - brown & 5.50 & 2.50 & 9.74 & 4.11 \\
\hline $\begin{array}{c}\text { IT89- } \\
\text { KD-374 }\end{array}$ & 0.00 & 0.00 & 8.33 & 3.86 \\
\hline $\begin{array}{c}\text { IT89- } \\
\text { KD-434 }\end{array}$ & 6.50 & 2.50 & 8.89 & 3.33 \\
\hline IT86-D-715 & 0.00 & 0.00 & 9.33 & 4.00 \\
\hline
\end{tabular}

\section{Effect of wound on heights of plants and grain weights of cowpea varieties}

It could be seen from the height of the unwounded plants (Table 3) the variety IT89-KD-434 had the highest average height of $28.33 \mathrm{~cm}$ while both IT89-KD-374 and IT-86-D-715 had the least average height of $19.33 \mathrm{~cm}$ each. On the other hand variety IT89-KD-434 had the highest average weights of seed of 
$14.00 \mathrm{~g}$ in the unwounded column while variety IT86-D-715 had the least average weights of seeds in the same column. Variety $\mathrm{L}-25$ had average weight of seed of $10.00 \mathrm{~g}$ while variety Ife brown had an average weight of seed of $8.08 \mathrm{~g}$ but did not had any value in the wounded column this might be attributable to its infestation by aphids

Table 3:Effect of wound on heights of plants and grain weights of cowpea varieties.

\begin{tabular}{|c|c|c|c|c|}
\hline \multirow{2}{*}{ Varieties } & \multicolumn{2}{|c|}{ Average Heights of Plant } & \multicolumn{2}{c|}{$\begin{array}{c}\text { Average Weights of } \\
\text { Seeds }\end{array}$} \\
\cline { 2 - 5 } & $\begin{array}{c}\text { Non } \\
\text { wounded }\end{array}$ & Wounded & $\begin{array}{c}\text { Non } \\
\text { wounded }\end{array}$ & Wounded \\
\hline L - 25 & 24.58 & 23.66 & 10.00 & 7.00 \\
\hline Ife - brown & 19.83 & 17.91 & 8.08 & 0.00 \\
\hline $\begin{array}{c}\text { IT89- } \\
\text { KD-374 }\end{array}$ & 19.33 & 20.41 & 7.80 & 10.50 \\
\hline $\begin{array}{c}\text { IT89- } \\
\text { KD-434 }\end{array}$ & 28.33 & 23.66 & 14.00 & 8.50 \\
\hline IT86-D-715 & 19.33 & 17.58 & 5.80 & 4.30 \\
\hline LSD & 4.81 & Ns & 2.61 & Ns \\
\hline
\end{tabular}

\section{Discussion}

Several, workers have noted that resistance of some plants increase with age, in their independent studies concluded that plants with woody stems and roots generally become more resistant with age $[2,3,7,17]$. Such plants include cotton, cowpea, soybeans, and Tomato, whereas plants with herbaceous and fleshy roots remained susceptible. Some herbaceous plants are however resistant throughout their life. Hibiscus sabdariffa. $L$. is reported to become more susceptible as it approaches maturity [18]. The nutritional importance of the cowpea crop to the resource poor farmers cannot be over emphasised. Therefore trial of this nature that screened different cowpea varieties for resistance to Sclerotium rolfsii would be of great benefit to farmer's cowpea breeders and pathologists. In this study, Ife brown and IT86-D-715 both had a higher percent establishment of 100 and 90 respectively. These values were significantly higher than 40,40 , and $50 \%$ establishment observed in the varieties L - 25, IT89-KD-374 and IT89-KD-434 respectively. Although the percent establishment for Ife - brown was more than the variety IT86-D-715. The two were not statistically different. In the percentage number of plants with necrotic lesion, Ife - brown and IT89-KD-434 were the only varieties that became infected after inoculation with mycelia disc of $S$. rolfsii. The infection did not cause death of the plants nor do the lesion increased in size. The lack of lesions in some varieties and lack of increase in the size of the lesions (in infected ones) may be due in part to in conducive environments and differential resistances to the pathogen by the cowpea varieties as reported by Thangavelu R [2]. High day temperature of 360C which is above that optimum 300C [16] within the screen house might have also accounted for lack of infection. Effects of the plant age at inoculation and woodiness may further confer resistance $[2,3,17]$. Analysis of this result however showed that there was no significant difference $(\mathrm{P}=0.05)$ between the varieties. This means that method of inoculation does not have any significant effect on infection. The per cent size of lesion is reflected only on the infected varieties (Ife brown and IT89-KD-434) however IT89-KD-434 had a higher value than Ife - brown and there is a significant difference between the varieties $(\mathrm{P}=0.05)$ with LSD of 3.840 between the infected varieties comparing the average size of lesions in the wounded and non-wounded, leads to the inference that lesion size aggravated more in Ife - brown than in other varieties when the varieties were injured or wounded hence could encourage infection by the pathogen [7]. There was a significant difference between the varieties in plant height as affected by wounding or unwounding. The variety IT89-KD-434 had the highest value of average plant height as well as highest value of average seed weight in the unwounded case. The least significant difference $(\mathrm{P}=0.05)$ is 4.81 in unwounded plants whereas no significant difference was observed in both wounded columns of average height of plant and average seed weight. This clearly shows that wounding does not significantly affect height of plants and seed weight of plants, and also does not affect plant susceptibility to infection of pathogen. The LSD $(\mathrm{P}=0.05)$ in the unwounded column for average seed weight is 2.61 .

\section{Conclusion}

Based on the analysis of the results obtained,

i. Ife - brown and IT86-D-715 established best than the other varieties tested.

ii. The varieties L-25, IT89-KD-374, and IT86-D-715 were resistant to infection by the pathogen while Ife-brown and IT89-KD-434 were susceptible

iii. The variety IT89-KD-434 gave the highest average plant height as well as average seed weight.

\section{Recommendation}

Ife - brown and IT86-D-715 are recommended for their establishment, while varieties L-25,IT89-KD-374 and IT86-D-715 are resistant to pathogen.IT89-KD-434 is recommended for its best average seed weight; hence it is recommended for cultivation in the study area.

There is need to carry out research to develop more cowpea varieties that are resistant to attack by the pathogen and other pathogens, that cause serious diseases to cowpea and other plant crops of economic importance. When these are obtained, they would be made available to farmers through sale of their seeds to them at subsidized rates.

\section{References}

1. Anonymous (2011) Production guidelines for cowpeas. Compiled by Directorate plant production in collaboration with the ARC obtainable from Resource centre, Directorate Agricultural Information Services P.M.B. X144 Pretoria, 0001 South Africa.

2. Thangavelu R, Mustapha MM (2010) First Report of Corn rot disease Caused by Sclerotium rolfsii in Banana. Australian Plant disease Notes 5(1): 30-33. 
3. Davies DW, Oelke EA, Oplinger ES, Doll JD, Hanson CV, et al. (2015) Alternative Field crops manual.

4. Richard LF, Philip DD (2002) Southern blight (Sclerotium rolfsii Sacc.) of Cowpea yield loss estimates and sources of resistance. Crop Protection 21(5): 403-408

5. Langyintuo AS, Lowenberg-DeBoer J, Faye M, Lamber D, Ibro G, et al (2003) Cowpea supply and demand in West Africa. Field Crops Res 82: 215-231.

6. Phillips AJ (2008) Factors affecting the parasitic activity of Gliocardium virens on Sclerotia of Sclerotinia Sclerotiorum and a note on its host range. Journal of Phytopathology.

7. Adandonon A, Aveling TA, Tamo M (2004) Occurrence and distribution of Cowpea damping-off and stem rot associated fungi in Benin. Journal of Agricultural Science 142(5): 561-566.

8. Barbara S, Alan H (2014) Sclerotium rolfsii (Southern stem rot of peanut). retrieved from wik.bugwood.org/Sclerotium rolfsii (Southern stem rot of peanut)

9. Stephen AF, Rebecca AB (1992) Southern Blight, Southern wilt (Plant diseases pathogen).

10. Sennoj R,Jogloy S,Saksiriva W and Patanothai A(2010): Pathogenecity Test of Sclerotiumrolfsii, a causal agent of stem rot (Jerusalem Artichoke - Helianthus tuberosus L.) Asian Journal of Plant Sciences 9: 281- 284
11. Mullen J (2006) Southern Blight,Southern stem blight,whitemold. The Plant Health Instructor DOI: 10.1094/PHI-2001-0104-01.

12. Shirdha C, Amit K C, Chaurasia S (2013) Factors Affecting the growth and sclerotial production in Sclerotium rolfsii, causing foot rot of Brinjal.

13. Okereke V C, Wokocha RC (2007) In Vitro growth of four isolates of Sclerotium rolfsii, Sacc in the humid tropics. African Journal of Biotechnology 6: 1879-1881

14. Fouzia Y, Saleem S (2015): Pathogenecity of Sclerotium rolfsii, and different crops and effect of Innoculum density on colonization of mungbean and sunflower roots.

15. Singh BB (2002) Recent genetic studies in cowpea. In: Fatokun CA, Tarawali SA, Singh BB, Kormawa PM, Tamo M (Eds.), Challenges and Opportunities for Enhancing sustainable Cowpea Production. Intl Inst Tropical Agric, Ibadan, Nigeria, pp. 3-13

16. Emechebe A M and Lagoke STO (1995) Recent advances in Research on Cowpea diseases.

17. Ramiah M, Narayanasary P, Subramanian CL (1976): Leaf Blight of Cowpea (Vigna sinensis) caused by Sclerotium rolfsii, sacc. Cur Sci 45 (a): 352

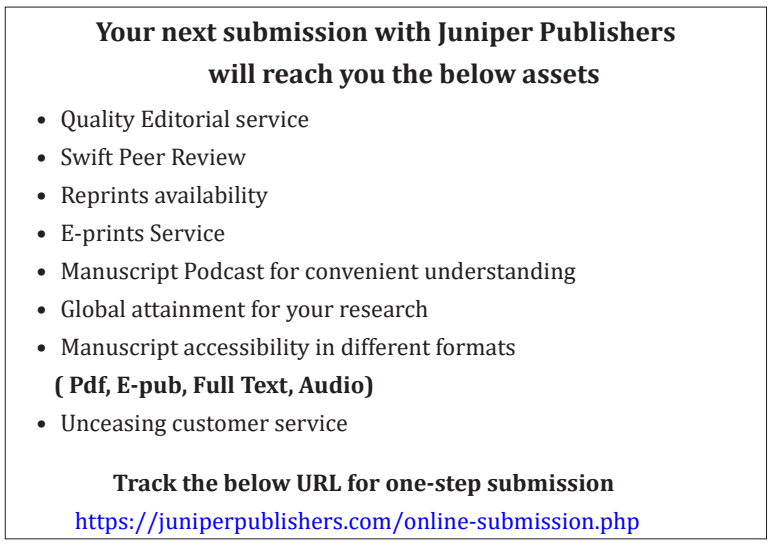

